\title{
Close vote and now a ballot on GPs' contract
}

\section{Doctors urged to vote on future of general practice}

Ministers should not misread the close vote to reject the revised contract package for NHS general practitioners. ${ }^{1}$ Representatives at the special conference of representatives of local medical committees ( $p$ 57) were broadly united in their dislike of the package, disagreeing mainly on the profession's tactical response to it. Out of 325 voting representatives the 166 who wanted no part of it defeated the 150 who were "reluctantly" prepared to have the package priced by the review body. On the day of a national transport strike the turn out was high and the vote was close enough to persuade the conference that a ballot of all general practitioners was necessary. All this should prompt the Secretary of State for Health to think carefully before imposing a revised contract, which he has the power to do (p 59) and which he warned parliament he would do if doctors rejected his renegotiated package.

General practitioners see the proposals as worsening the care of patients and are worried at the further restraints on their independence. Dr Wilson and the other negotiators from the General Medical Services Committee judged after many hours of negotiations over the past 18 months that the proposals were the best they could obtain. The government has a large parliamentary majority, ample legislative time, and the determination to force through a new contract based on its philosophy that competition improves the service to the public.

The primary objections to the original contract ${ }^{2}$ had been to the

- Higher proportion of income from capitation fees, seen as rolling back the gains of the family doctor charter by leading to larger list sizes with poorer services for patients

- Rigid targets for immunisation and cervical cytology screening, which would be unachievable in many areas

- The two tier system of fees for night work with a lower fee for doctors or partnerships not doing their own visits

- Loss of seniority payments.

In their 10 hour meeting on 4 May with Kenneth Clarke the negotiators had modified the basis of capitation payments, agreed two stage targets for payments for immunisation and cervical cytology, ensured that extended rotas would attract the higher night visit fee, and restored seniority payments. And since 4 May further improvements had been negotiated, as Dr Wilson told the conference (p 58).

Some representatives were prepared for the revised contract to be priced because they thought further improvements unlikely. They believed that it was in the interests of patients and doctors for the GMSC to help revise the statement of fees and allowances (the substantial and practical interpretation of the contract). Cooperation now might make further improvements achievable, and agreement on the contract would leave doctors free to concentrate on limiting the damage from the NHS review.

Those who opposed the negotiators' recommendation did not see why doctors should cooperate in introducing flawed proposals. They were prepared for the Secretary of State to impose a contract, arguing that this would leave the profession on the moral high ground when the consequences turned out to be a worse service for the public. Convinced that the government's political position was weakening, they also believed that determined resistance by doctors would lead to further government concessions.

After the meeting rejected the negotiators' advice it backed a call for negotiations to be reopened-a call that Kenneth Clarke dismissed with the comment that "You cannot negotiate with trade union negotiators and have them come back and say the lads don't want it and try to reopen a deal which they themselves have commended to their own conference." Nevertheless, Mr Clarke might be wise to leave his options open because the ballot might well be affected by such remarks.

Two things will be crucial in this ballot-which way general practitioners vote and how many vote. The fact that Kenneth Clarke is going ahead with laying regulations before parliament to enable him to introduce some sort of contractwhich version he has not yet said-should not deter doctors from voting. It will be several weeks before regulations reach parliament, and it could be the autumn before they can be debated.

General practitioners have been sent all the information they need, and many have attended meetings to discuss the contract. As they face the biggest change in general practice since the charter they have a responsibility to vote for their craft and their patients. A large vote (at least $75 \%$ ) will tell the Secretary of State that the contract is of great concern to general practitioners. Should the outcome favour the contract package, that could persuade him to introduce the revised version, presumably with the cooperation of the BMA. Should it be rejected he should reflect whether pushing on with his competitive contract will be in the best interests of the public, for whose health he has the ultimate responsibility.

Deputy Editor,
$B M \mathcal{F}$

GORDON MACPHERSON

1 General Medical Services Committee. Report to a special conference of representatives of local medical committees on 21/22 fune 1989. SC2. London: GMSC, 1989.

2 Department of Health and Welsh Office. General practice in the National Health Service. A new contract. London: DoH, 1989. 